Published in final edited form as:

Semin Immunol. 2017 April ; 30: 36-44. doi:10.1016/j.smim.2017.08.008.

\title{
Oral immunotherapy for food allergy
}

\author{
Deborah M. Hussey Freelanda,b, Monali Manohara,b, Sandra Andorfa,b, Benjamin D. \\ Hobson $^{b}$, Wenming Zhang ${ }^{\mathrm{a}, \mathrm{b}}$, and Kari C. Nadeau, ${ }^{\mathrm{a}, \mathrm{b}, \mathrm{c},{ }^{*}}$ \\ aSean N. Parker Center for Allergy and Asthma Research at Stanford University, Stanford \\ University, Stanford, CA 94305, USA \\ bivision of Pulmonary and Critical Care Medicine, Stanford University, Stanford, CA 94305, USA \\ 'Division of Allergy, Immunology and Rheumatology, Department of Medicine, Stanford University, \\ Stanford, CA 94305, USA
}

\section{Abstract}

Food allergy is a pathological, potentially deadly cascade of immune responses to molecules or molecular fragments that are normally innocuous when encountered in foods, such as milk, egg, or peanut. As the incidence and prevalence of food allergy rise, the standard of care is poised to advance beyond food allergen avoidance coupled with injectable epinephrine treatment of allergen-induced systemic reactions. Recent studies provide evidence that oral immunotherapy may effectively redirect the atopic immune responses of food allergy patients as they ingest small but gradually increasing allergen doses over many months, eliciting safer immune responses to these antigens. Research into the molecular and cellular bases of pathological and therapeutic immune responses, and into the possibilities for their safe and effective modulation, is generating tremendous interest in basic and clinical immunology. We synthesize developments, innovations, and key challenges in our understanding of the immune mechanisms associated with atopy and oral immunotherapy for food allergy.

\section{Keywords}

Antigen-specific; Epitope; Oral food challenge; Sustained unresponsiveness; T helper 2 cell; Tolerogenic

\section{Introduction}

Food allergy affects $8 \%$ of children and $5 \%$ of adults in the U.S. [1,2], and epidemiological data generally indicate an increase in its prevalence [2]. However, the current standard of care for all food allergies is minimal, consisting of food-allergen avoidance and emergency treatment of potentially fatal allergen-induced systemic reactions with injectable epinephrine; the constant risk of severe allergic reaction adversely impacts the quality of life of food-allergy patients and their families. The growing, global, unmet need for safe and

\footnotetext{
*Corresponding author at: Sean N. Parker Center for Allergy and Asthma Research at Stanford University, CCSR 3215c, Stanford University, Stanford, CA 94305, USA. knadeau@ stanford.edu (K.C. Nadeau).
} 
effective treatment can best be met by understanding the cellular and molecular mechanisms of promising immunotherapeutic approaches under clinical investigation [3].

The mechanistic role of $\mathrm{IgE}$ in atopic immune responses provides a useful distinction among types of food allergy: IgE-mediated food allergy is characterized by acute, potentially lifethreatening immune responses, while non-IgE-mediated food allergy is driven by slower, cell-mediated responses. This review focuses on IgE-mediated food allergy, in which food allergen epitopes bind to IgE molecules which also bind FceRI receptors on immune effector cells, such as basophils, mast cells, and antigen-presenting dendritic cells. Epitopespecific cross-linking of the IgE-bound receptors results in degranulation of basophils and mast cells, releasing pre-formed histamine and other inflammatory molecules that generate a rapid atopic reaction [4]. Additional inflammatory mediators, such as platelet activating factor, leukotrienes and the cytokines interleukin-4 (IL-4), IL-5, and IL-13, are then produced de novo, augmenting the inflammatory immune response [4]. Membrane-bound $\mathrm{IgE}$ on $\mathrm{B}$ cells also forms a complex with $\mathrm{CD} 23$ and $\mathrm{CD} 21$, increasing production of soluble $\operatorname{IgE}[5]$ and escalating the IgE-mediated immune response. The resulting symptoms may include gastrointestinal responses (e.g., pruritus, abdominal pain, nausea, vomiting), respiratory responses (e.g., airway inflammation, wheezing), dermal responses (e.g., pruritus, angioedema, urticaria), and systemic responses (e.g., hypotension, hypothermia). An anaphylactic response involves multiple organ systems and rapidly may become lifethreatening [6].

Recent clinical studies reviewed here provide evidence that oral immunotherapy (OIT) can be used safely and effectively to reduce the sensitivity of food allergy (FA) patients to food antigens (Ag). However, it is not yet clear the extent to which such patients develop desensitization (DS, defined as a lack of clinical reactivity to Ag, the maintenance of which requires regular Ag exposure), as distinct from sustained unresponsiveness (SU), in which the patient exhibits a long-term and perhaps permanent loss of reactivity to Ag that is independent of continued $\mathrm{Ag}$ exposure. Novel findings from our group and others are elucidating the mechanisms by which DS and SU are established through OIT.

In OIT, FA study participants ingest small but gradually increasing doses of specific food Ag over the course of several months, with the goal of progressively retraining their immune responses to establish DS and possibly SU to the Ag (Fig. 1) [7]. Because other FA diagnostic tools, such as measurements of blood levels of Ag-specific IgE and skin-prick tests, are known to generate false positives that could confound research results [8,9], an initial, definitive FA diagnosis is made using a double-blind, placebo-controlled, oral food challenge (DBPCFC) with one or more target Ag. On the first day of OIT, the participant ingests increasing doses of the target Ag under clinical care to determine the highest tolerated dose. After this initial-day dose escalation, the highest tolerated dose is used to begin a dose-escalation phase, in which the dose is increased in a visit to the clinic every 1-2 weeks until the designated maintenance dose is tolerated. Then, during the maintenance phase which ranges from months to years, the participant daily ingests the maintenance dose of the FA. A desensitization DBPCFC is administered in the clinic at the end of the maintenance phase, to assess the efficacy of the treatment protocol. If a statistically significant increase in the tolerated dose to a level that is protective against accidental $\mathrm{Ag}$ 
exposure is found, the OIT is deemed successful. DS, or a reduction in adverse immune response that is maintained through regular Ag exposure, is often achieved through OIT, along with lower risk of anaphylaxis and increased quality of life for FA participants and their families.

To test for SU, an Ag avoidance phase of weeks to months may be added after the termination of OIT, ending with a followup DBPCFC. If the target dose is tolerated after the avoidance phase, the participant has achieved SU to that dose, a reduced immune response to $\mathrm{Ag}$ that persists even without continued, regular Ag exposure. Since a DBPCFC is not prospective, the duration and variance of SU are unknown. The mechanisms underlying SU, its potential durability and defeat, and its comparison to healthy tolerance are promising research areas that could be of tremendous benefit to our understanding of healthy, atopic, and therapy-induced immune states.

The field of FA OIT is very active and growing. This review focuses on recent, peerreviewed studies, prioritizing phase II trials with a placebo arm, clearly defined dosing, and those that required a screening DBPCFC (sDBPCFC) to avoid confounding due to false positive FA diagnoses. We also prioritize studies with associated, long-term followup to assess SU, and associated mechanistic studies. We highlight recent advances in the safety, efficacy, and mechanistic understanding of OIT.

\section{Immune mechanisms}

The immunological mechanisms of: (1) the establishment and maintenance of a healthy state of immune tolerance to food antigens; (2) food allergy; and (3) desensitization established through OIT are drawing increasing research interest. The evolution of this research is addressed in several recent reviews [10-16]; key features are outlined here. While we focus on food allergy research in humans, we also cite relevant hypotheses based on research in closely related atopic diseases, and in mouse models.

\subsection{Tolerance}

The variety of cells forming the healthy intestinal epithelium present a selective barrier to food antigens in the intestinal lumen (Fig. 2). Segmented, filamentous bacteria (SFB) and secreted, dimeric IgA promote homeostasis at the luminal surface [17]. SFB may induce IL-17- and IL-22-producing CD4 ${ }^{+}$T helper cells (Th17) in the lamina propria [18]. In Peyer's patches, Th17 may convert to T follicular helper cells (Tfh) and contribute to IL-21mediated B-cell homing and secretion of $\operatorname{IgA}[19]$.

Food Ag are taken up by absorptive enterocytes [15], and are also sampled directly from the lumen by $\mathrm{CD}_{103}{ }^{+}$dendritic cells (DC), which can extend a process through the transcellular pore of a micro-fold (M) cell in a Peyer's patch [20], or through a tight junction between epithelial cells [21]. $\mathrm{CX}_{3} \mathrm{CR}^{+}$macrophages also sample luminal food $\mathrm{Ag}$, and can transfer Ag directly to DC [22,23].

Ag-bearing DC then migrate to a draining lymph node and present antigen to naïve CD4+ T cells, producing TGF $\beta$ and retinoic acid to promote the induction of Ag-specific, FoxP3 ${ }^{+}$ 
regulatory $\mathrm{T}$ cells $\left(\mathrm{T}_{\text {reg }}\right)[22,24-26] . \mathrm{T}_{\text {reg }}$ then express gut-homing markers such as $\alpha 4 \beta 7$ and return to the lamina propria [27], where they produce IL-10 and TGF $\beta$, potentially inhibiting mast cell degranulation [28] and sustaining tolerance [10,29]. $\mathrm{CX}_{3} \mathrm{CR} 1^{+}$ macrophages also produce IL-10, contributing to the induction of $\mathrm{T}_{\text {reg }}$ in the lamina propria $[30,31]$.

\subsection{Atopy}

Cellular and molecular mechanisms underlying T helper 2 cell-mediated atopic response to food antigens are outlined in Fig. 3. It is possible that exposure to food allergens through a compromised epithelial barrier in the skin may lead to allergic sensitization [32]; atopic dermatitis is the first step of the atopic march to food allergy [33,34]. In the gastrointestinal tract, epithelial damage allows food Ag to bypass the selective mechanisms of transport into the lamina propria, prompting the release of the alarmins IL-25, IL-33 and thymic stromal lymphopoietin (TSLP), epithelium-derived cytokines implicated in initiating inflammatory immune responses mediated by T helper 2 cells (Th2) [35]. IL-25 stimulates type 2 innate lymphoid cells (ILC2) and drives ILC2 production of the inflammatory cytokine IL-13 [36,37]. With TSLP, IL-25 promotes the development of T helper 9 cells (Th9) which produce IL-9 [38-41], which in turn prompts the accumulation and activation of mast cells [42]. IL-33 contributes to ILC2 expansion and production of the inflammatory cytokine IL-4 [43]. TSLP has been shown to activate ILC2 [35], as well as DC that prime the differentiation of naïve $\mathrm{CD} 4^{+} \mathrm{T}$ cells into Th2 [44]; the latter activation may occur through upregulation of OX40L on the DC surface [45]. TSLP also activates DC that drive the differentiation of Tfh which help memory B cells to produce IgE via an IL-4- and/or IL-13dependent mechanism [46].

Both ILC2 and Th2 cells produce IL-4, IL-5 and IL-13 [47,48]. IL-4 inhibits Treg function, activates mast cells [43], and drives Treg reprogramming into Th2 [49]. IL-5 promotes the development and maintenance of eosinophils associated with atopic reaction [50]; with IL-13, IL-5 promotes eosinophil accumulation [51]. IL-13 also prompts DC homing to the draining lymph nodes to promote the conversion of naïve $\mathrm{CD} 4^{+} \mathrm{T}$ cells into $\mathrm{Th} 2$ [52].

\subsection{Desensitization}

Exploration of the immune mechanistic similarities and differences among health and the desensitization and SU that can be established by OIT is becoming increasingly feasible as more clinical trials enter long-term followup; selected mechanisms are outlined in Fig. 4. Over the course of OIT, Ag-specific Th2 become apoptotic [53] and anergic [54], and Aginduced Treg function increases as methylation of the forkhead box protein 3 (FOXP3) gene in these cells decreases [55].

In healthy individuals, $\mathrm{Ag}$-specific $\mathrm{CD} 4^{+}$Treg and type 1 regulatory $\mathrm{T}$ cells $(\mathrm{Tr} 1)$ secrete IL-10, which suppresses IgE production while inducing that of $\operatorname{IgG}_{4}[56]$; in OIT, Agspecific IgE decreases while $\mathrm{IgG}_{4}$ increases [57]. Studies of Ag-specific immunotherapy for the major bee venom $\mathrm{Ag}$, phospholipase $\mathrm{A}_{2}$, suggest that $\mathrm{Ag}$-specific type $1 \mathrm{~B}$ regulatory cells (Breg) increasingly produce IL-10 over the course of immunotherapy, contributing to $\mathrm{IgG}_{4}$ production [58,59] and inhibiting IgE-dependent mast cell activation [60]. $\mathrm{IgG}_{4}$ has 
been shown to inhibit Ag-induced mast cell and basophil activation [61]; Treg also inhibit mast cells by contact, via OX40-OX40L interaction [28]. As desensitization develops through Ag-specific immunotherapy, mast cell and basophil activation are suppressed [62].

Treg also inhibit DCs required for the activation of effector $\mathrm{T}$ cells, perhaps via cytotoxic $\mathrm{T}$ lymphocyte antigen 4 (CTLA4)- [63] or lymphocyte activation gene 3 (LAG3)- [64,65] mediated interaction [66].

In egg OIT, high Ag-specific IgA levels at baseline have been associated with response to therapy [57], and increase in $\mathrm{Ag}$-specific $\operatorname{IgA}_{2}$ levels from below the control level at baseline have been observed in egg-allergic children [67].

\section{Oral immunotherapy (OIT) strategies}

\subsection{OIT}

OIT trials are very valuable resources for the study of the cellular and molecular mechanisms by which FA pathology and treatment are effected. For example, a pilot study to examine the role of invariant natural killer T cells (iNKT) in OIT was performed with 11 highly allergic children having a history of anaphylaxis to cow's milk and a positive sDBPCFC [68]. An open course of lactose-free cow's milk OIT was given, with antihistamine and with a protocol for temporary dose reduction during illness, but without placebo, building up to a maintenance dose of $8 \mathrm{~g}$ cow's milk protein or 8 ounces cow's milk over 3-7 months. $90 \%$ of participants reached and continued at the maintenance dose for at least 12 weeks, demonstrating the safety and efficacy of the OIT, which the authors suggest may have been enhanced by the use of antihistamines and reduced dosing during illness.

iNKT are responsive to lipids presented by CD1d, and are able to secrete both Th1 and Th2 cytokines [68]. Peripheral blood iNKT were sorted via flow cytometry to assess their induction, and stimulated with milk sphingomyelin and a positive and a negative control to assess their cytokine production profiles at baseline, after reaching maintenance dose, and after 12 weeks at the maintenance dose. Peripheral blood iNKT, which occur at lower levels in children with cow's milk allergy, were significantly induced by OIT. These iNKT also exhibit Th2-skewing in cow's milk allergic children, and OIT was found significantly to shift their cytokine profile from Th 2 to Th1, increasing IFN $\gamma$ production and decreasing that of IL-4 and IL-13. This pilot study suggests a role for iNKT in FA that may provide helpful targets for treatment.

\subsection{OIT with blocking antibodies}

Allergen-specific blocking antibodies can play important roles in allergen-specific immunotherapies such as OIT $[69,70]$. Since IgE plays a key role in IgE-mediated food allergy, the deployment of antibodies against IgE is an important strategy for increasing the efficacy of OIT. However, if an anti-IgE Ab were to bind not only to soluble IgE, but also to IgE bound to its FceRI receptors on immune effector cells, then the anti-IgE may have the same effect as a food Ag epitope, cross-linking the bound $\mathrm{IgE}$ and triggering a cascade of inflammatory immune responses. 
Omalizumab is a humanized monoclonal antibody ( $\mathrm{mAb}$ ) against $\operatorname{IgE}$ that binds to free $\operatorname{IgE}$ in the bloodstream, blocking the interaction of $\operatorname{IgE}$ with FceRI receptors, thereby effectively reducing the amount of IgE available to trigger the release of inflammatory mediators from basophils and mast cells [5]. Omalizumab also binds to membrane-bound IgE, and thus can block increased IgE production by B cells [71]. However, omalizumab does not bind to IgE that is already bound to either FceRI or CD23, so that omalizumab does not trigger the inflammatory cascade. Further, surface FceRI is unstable when not bound to IgE, so that reducing the IgE available to bind FceRI results in the downregulation of FceRI on the surfaces of immune effector cells, mitigating basophil [72] and mast cell [73] activation as well as antigen presentation by dendritic cells to T cells [74]. Circulating IgE bound to omalizumab may still be able to bind food Ag epitopes, so that free Ag levels are also reduced [75]. Several trials explore the role of omalizumab as an IgE-blocking $\mathrm{mAb}$ adjuvant to OIT, testing its effects on OIT safety and efficacy.

A randomized, multi-site, double-blind, placebo-controlled, clinical trial of cow's milk OIT tested whether the use of omalizumab as an adjuvant improved the safety or efficacy of OIT [76]. 57 participants with milk allergy confirmed by SDBPCFC were randomized into either an omalizumab or a placebo treatment group; after 4 months of treatment, OIT was initiated. Omalizumab was discontinued at 28 months, at which point participants who passed a DBPCFC were deemed to have achieved DS. OIT was discontinued at 30 months, and those who passed a DBPCFC at 32 months were deemed to have achieved SU. Though the efficacy outcomes (DS and SU) did not differ significantly between the omalizumab and placebo groups, those in the omalizumab group required significantly fewer OIT doses to achieve the maintenance dose, and safety outcomes were significantly improved.

A mechanistic study of blood samples collected from these participants throughout the study investigated the effects of omalizumab on Ag-induced basophil and T cell activation, and sought to identify predictive biomarkers of benefit from the addition of omalizumab to OIT [77]. No significant increase in the percentage of casein-specific regulatory T cells was observed in OIT in either group. However, participants with higher basophil reactivity (indicated by surface expression of CD63) at baseline had higher adverse reaction rates, and CD63 was significantly decreased at the 3 highest concentrations of milk in the omalizumab arm compared to the placebo arm throughout the omalizumab treatment period. Lower baseline milk IgE/total IgE ratios were found among subjects who achieved SU: this correlation was highly significant in the omalizumab arm, but not in the placebo arm. These findings suggest that these two biomarkers taken together may be predictive of the greatest benefit from the use of omalizumab as an adjuvant to OIT. In addition, participants who reached DS had both lower CD63 expression at 1 and $10 \mu \mathrm{g} / \mathrm{mL}$ milk stimulant and higher casein-specific and $\beta$-lactoglobulin-specific $\mathrm{IgG}_{4} / \mathrm{IgE}$ ratios at the week $28 \mathrm{DBPCFC}$, as did those who reached SU at the week 32 DBPCFC, showing significant correlations between these concurrent biomarkers and DS and SU clinical outcomes.

A randomized, double-blind, placebo-controlled study of peanut OIT evaluated whether the use of omalizumab as an adjuvant could facilitate rapid DS in highly peanut allergic participants [78]. 37 participants with peanut allergy established by sDBPCFC were randomized into either an omalizumab or a placebo treatment group; after 12 weeks of 
treatment, participants began OIT with a rapid DS period of up to $250 \mathrm{mg}$ peanut protein in one day. Those who tolerated this DS procedure continued with 8 weeks of updosing to reach a target dose of $2000 \mathrm{mg}$ peanut protein. Ability to tolerate $2000 \mathrm{mg}$ of peanut protein at 6 weeks after the withdrawal of study drug (primary endpoint) was assessed; those passing this assessment continued on OIT at this dose and underwent an open food challenge with $4000 \mathrm{mg}$ peanut protein at 12 weeks after the withdrawal of study drug (secondary endpoint). Statistically significant findings include: the highest tolerated peanut protein dose at the initial rapid DS was over an order of magnitude higher for those in the omalizumab group; and the proportions of this group reaching the primary and the secondary endpoints were $\sim 6$ times higher than those of the placebo group (Table 1). The use of IgE-blocking omalizumab in conjunction with OIT facilitated rapid DS over as few as 8 weeks, and for most DS participants, DS could be maintained after omalizumab withdrawal.

A phase I, single-site trial was the first to test whether omalizumab could be used in conjunction with OIT to achieve desensitization to multiple food allergens rapidly and simultaneously [79]. 25 children with multiple sDBPCFC-diagnosed food allergies were treated with omalizumab for 8 weeks before starting OIT for up to 5 food allergens concurrently; omalizumab treatment continued for the first 8 weeks of OIT. The median time to reach the maintenance dose of $4 \mathrm{~g}$ per food allergen was 18 weeks, which was 67 weeks earlier than the median time to achieve desensitization to $4 \mathrm{~g}$ per allergen than could be achieved by OIT alone, with comparable safety [80].

A mechanistic study of blood samples collected at 0,9 , and 18 months from a subset of these participants, and from a control group on food-allergen avoidance, examined changes in T cell clonotype associated with OIT + omalizumab [81]. Sequences of the TCR- $\beta$ of peanut-responsive CD4+ T cells were assessed for changes in clonal distribution and compared with the unstimulated, whole $\mathrm{T}$ cell repertoire. Peanut-responsive $\mathrm{T}$ cell clones were found to be highly diverse, and only $6 \%$ of the clones identified at a given time point persisted to the next, regardless of treatment group. While the relative frequency of each clone in the persistent, perhaps stable memory, population did not change in the control group, a change in clonal distribution over the course of OIT was observed. These results suggest that $\mathrm{T}$ cell replacement may be a contributing mechanism to the establishment of desensitization via OIT.

Recently published crystal structures of omalizumab provide information on its binding epitopes that could be used to engineer additional molecules to complement the immunotherapeutic effects of omalizumab [5,82]. Alternatively, $\operatorname{IgG}_{4}$ is thought also to act as a blocking antibody, competing with IgE for binding sites on Ag epitopes. Since various peanut OIT studies have found $\mathrm{IgG}_{4}$ to increase significantly with treatment, a study compared the inhibition of peanutinduced activation of basophils and mast cells by $\mathrm{IgG}_{4}$ in peanut-sensitive (but tolerant) children and PA children [61]. The ratio of peanut-specific $\mathrm{IgG}_{4}$ to peanut-specific IgE was significantly higher in peanut-sensitive but tolerant (PS) patients than in PA patients. Peanut-induced activation of mast cells and basophils from a PA patient was inhibited by plasma from PS patients, as well as by plasma from peanut OIT participants. When these inhibitory plasmas were depleted of $\mathrm{IgG}_{4}$ and their effects retested, 
mast cell inhibition was reduced. This study suggests that the clinical effectiveness of $\operatorname{IgG}_{4}$ as a blocking $\mathrm{Ab}$ that may increase the efficacy of OIT warrants exploration. Other studies indicate that $\mathrm{CD} 23$ may play a major role in IgE-facilitated allergen presentation to T cells, so that the inhibition of this process by allergen-specific IgG blocking antibodies could be a major mechanism for the reduction of $\mathrm{T}$ cell activation in the course of allergen-specific OIT [83-87].

In addition to IgE, other mediators of the atopic response diagrammed in Fig. 2 may be targeted by blocking Abs (Table 1). For example, the IL-33 receptor, ST2, when knocked out in a mouse model of house dust mite or peanut allergy, demonstrated the necessity of IL-33 mediation to establishing a Th2-mediated atopic response [88]; interfering with IL-33-ST2binding, and thus interfering with ILC2 activation and IL-4 production, may be a fruitful therapeutic approach $[43,89]$. In addition, the accumulation of eosinophils associated with the Th2-mediated atopic response may be mitigated by blocking IL-5-mediated signaling using an anti-IL-5 Ab, such as mepolizumab [90], or reslizumab [91].

\subsection{Further promising therapeutic strategies}

A very different adjuvant strategy for OIT was tested in a randomized, double-blind, placebo-controlled trial of peanut OIT with the probiotic Lactobacillus rhamnosus CGMCC 1.3724, which may promote Treg induction and Th1 cytokine responses [92]. Specific IgE levels and SPT results above the 95\% positive predictive values for clinical peanut allergy were used to determine allergic status; a SDBPCFC was not required due to ethical concerns. Sixty-two peanut-allergic children (1-10 years old) were randomized into OIT + adjuvant and placebo groups; the 18-month treatment consisted of a 1-day rush induction phase, an 8month buildup phase with updosing every 2 weeks to reach the $2000 \mathrm{mg}$ maintenance dose of peanut protein, and a 10-month maintenance phase. A DBPCFC to $4000 \mathrm{mg}$ peanut protein was performed on the final day of treatment to assess DS; those who passed eliminated peanut from their diet for at least 2 weeks and underwent a second DBPCFC to $4000 \mathrm{mg}$ peanut protein to test for SU (the authors acknowledge that an elimination period of at least 4 weeks is now advisable). While the results are striking in that $89.7 \%$ of participants receiving OIT + adjuvant achieved DS compared to $7.1 \%$ of those receiving placebo ( $p<0.001$ ), and $82.1 \%$ of participants receiving OIT + adjuvant achieved SU compared to $3.6 \%$ of those receiving placebo $(p<0.001)$, no comparison was made to the efficacies of OIT alone or to the administration of probiotic alone. The use of probiotics as adjuvants to increase OIT efficacy warrants further investigation.

A study of sublingual immunotherapy noted that while OIT can induce desensitization to far greater doses of Ag than can SLIT, SLIT may be useful as a means to progress to OIT in the highly allergic, and may also be a useful route for the administration of adjuvants to OIT [93].

\section{Further mechanistic insights}

Mechanistic studies of different immune cell subsets during short- and long-term courses of OIT are important to perform, to try to discover new targets for rational drug design in food allergy in the future. For example, a study was recently published using peripheral blood 
mononuclear cells (PBMCs) from 21 peanut-allergic (PA) individuals and 7 healthy controls to determine whether functional peanut-specific type 1 regulatory $T$ cells $(\operatorname{Tr} 1)$, which are potent immune response suppressors, could be induced in PA individuals at baseline or after short-term (3 - 12 months) or long-term (> 3 years) OIT [94]. Dendritic cells (DC) were differentiated from PBMCs in the presence of IL-10 and pulsed with peanut Ag Ara h 1 and 2; resulting tolerogenic DC-10 were used as antigen-presenting cells to induce a subset of Tr1 cells from autologous CD4+ T cells in vitro in the presence of IL-10. While similar levels of peanut-specific Tr1 could be induced from these CD4+ T cells of individuals in all 4 study groups, the CD4+ T cells of healthy controls tended to be anergic, while those from all PA groups exhibited high Th2 cytokine production. Since induced Tr1 were Ag-specific and expressed gut-homing receptors, it appears that they lack the functional capacity to inhibit Th2 responses in PA individuals [94]. In separate studies, the flow cytometry analysis of PBMCs collected during the maintenance phase from peanut-allergic OIT participants treated with [79] and without [80] adjunctive omalizumab showed significant decreases in $\mathrm{IL}-4^{+}$peanut-specific CD4+ T cells from the OIT $(n=11, p=0.004)$ and OIT + omalizumab ( $n=10, p=1.8 \mathrm{e}-06)$ groups, each compared to those of untreated peanutallergic controls $(n=13)$, possibly indicating a shift away from a Th2 phenotype (Fig. 5; Manohar, Andorf, et al., unpublished data).

\section{Conclusion}

As oral immunotherapy advances the management and prevention of food allergy, research aimed at its molecular and cellular mechanisms advances our understanding of healthy, pathological, and therapeutic human immune responses. Innovations to extend the safety and efficacy of OIT prominently include the use of blocking antibodies as adjuvants to OIT, interfering with various effector pathways that otherwise could bring about the clinical manifestations of IgE-mediated atopic immune response. Mechanistic research focused on the establishment of healthy immune tolerance to foods, and on the durability and defeasibility of sustained unresponsiveness to food antigens effected by OIT, promises very significant advances in the immunology and treatment of food allergy.

\section{Acknowledgments}

The authors would like to thank Vanitha Sampath for creating Figs. 2-4 and the bibliography. This work was supported by NIH grant U19AI104209, the Bezos Family Foundation, the FARE Center of Excellence, the Myra Reinhard Foundation, and the Sean N. Parker Center for Allergy and Asthma Research at Stanford University.

\section{References}

1. Gupta RS, Springston EE, Warrier MR, Smith B, Kumar R, Pongracic J, Holl JL. The prevalence, severity, and distribution of childhood food allergy in the United States. Pediatrics. 2011; 128:e917. [PubMed: 21690110]

2. Sicherer SH, Sampson HA. Food allergy: epidemiology, pathogenesis, diagnosis, and treatment. J. Allergy Clin. Immunol. 2014; 133:291-307. [PubMed: 24388012]

3. Jones SM, Burks AW, Dupont C. State of the art on food allergen immunotherapy: oral, sublingual, and epicutaneous. J. Allergy Clin. Immunol. 2014; 133:318-323. [PubMed: 24636471]

4. Stone KD, Prussin C, Metcalfe DD. IgE, mast cells, basophils, and eosinophils. J. Allergy Clin. Immunol. 2010; 125:S73-80. [PubMed: 20176269] 
5. Wright JD, Chu HM, Huang CH, Ma C, Chang TW, Lim C. Structural and physical basis for antiIgE therapy. Nat. Sci. Rep. 2015; 5:11581.

6. Sampson HA, Munoz-Furlong A, Campbell RL, Adkinson NF Jr, Bock SA, Branum A, Brown SG, Camargo CA Jr, Cydulka R, Galli SJ, Gidudu J, Gruchalla RS, Harlor AD Jr, Hepner DL, Lewis LM, Lieberman PL, Metcalfe DD, O'Connor R, Muraro A, Rudman A, Schmitt C, Scherrer D, Simons FE, Thomas S, Wood JP, Decker WW. Second symposium on the definition and management of anaphylaxis: summary report-second National Institute of Allergy and Infectious Disease/Food Allergy and Anaphylaxis Network symposium. J. Allergy Clin. Immunol. 2006; 117:391-397. [PubMed: 16461139]

7. Nadeau KC, Kohli A, Iyengar S, DeKruyff RH, Umetsu DT. Oral immunotherapy and anti-IgE antibody-adjunctive treatment for food allergy. Immunol. Allergy Clin. North Am. 2012; 32:111133. [PubMed: 22244236]

8. Sato M, Shukuya A, Sato S, Komata T, Utsunomiya T, Imai T, Tomikawa M, Ebisawa M. Oral challenge tests for soybean allergies in Japan: a summary of 142 cases. Allergol. Int. 2016; 65:6873. [PubMed: 26740299]

9. Kattan JD, Wang J. Allergen component testing for food allergy: ready for prime time? Curr. Allergy Asthma Rep. 2013; 13:58-63. [PubMed: 23011598]

10. Noval Rivas M, Chatila TA. Regulatory T cells in allergic diseases. J. Allergy Clin. Immunol. 2016; 138:639-652. [PubMed: 27596705]

11. du Toit G, Tsakok T, Lack S, Lack G. Prevention of food allergy. J. Allergy Clin. Immunol. 2016; 137:998-1010. [PubMed: 27059727]

12. Wawrzyniak M, O'Mahony L, Akdis M. Role of regulatory cells in oral tolerance. Allergy Asthma Immunol Res. 2017; 9:107-115. [PubMed: 28102055]

13. Yu W, Freeland DM, Nadeau KC. Food allergy: immune mechanisms, diagnosis and immunotherapy. Nat. Rev. Immunol. 2016; 16:751-765. [PubMed: 27795547]

14. Chinthrajah RS, Hernandez JD, Boyd SD, Galli SJ, Nadeau KC. Molecular and cellular mechanisms of food allergy and food tolerance. J. Allergy Clin. Immunol. 2016; 137:984-997. [PubMed: 27059726]

15. Menard S, Cerf-Bensussan N, Heyman M. Multiple facets of intestinal permeability and epithelial handling of dietary antigens. Mucosal Immunol. 2010; 3:247-259. [PubMed: 20404811]

16. Valenta R, Hochwallner H, Linhart B, Pahr S. Food allergies: the basics. Gastroenterology. 2015; 148:1120-1131 e1124. [PubMed: 25680669]

17. Hirota K, Turner JE, Villa M, Duarte JH, Demengeot J, Steinmetz OM, Stockinger B. Plasticity of Th17 cells in Peyer's patches is responsible for the induction of T cell-dependent IgA responses. Nat. Immunol. 2013; 14:372-379. [PubMed: 23475182]

18. Ivanov II, Atarashi K, Manel N, Brodie EL, Shima T, Karaoz U, Wei D, Goldfarb KC, Santee CA, Lynch SV, Tanoue T, Imaoka A, Itoh K, Takeda K, Umesaki Y, Honda K, Littman DR. Induction of intestinal Th17 cells by segmented filamentous bacteria. Cell. 2009; 139:485-498. [PubMed: 19836068]

19. Cao AT, Yao S, Gong B, Nurieva RI, Elson CO, Cong Y. Interleukin (IL)-21 promotes intestinal IgA response to microbiota. Mucosal Immunol. 2015; 8:1072-1082. [PubMed: 25586558]

20. Lelouard H, Fallet M, de Bovis B, Meresse S, Gorvel JP. Peyer's patch dendritic cells sample antigens by extending dendrites through $\mathrm{M}$ cell-specific transcellular pores. Gastroenterology. 2012; 142:592-601 e593. [PubMed: 22155637]

21. Farache J, Koren I, Milo I, Gurevich I, Kim KW, Zigmond E, Furtado GC, Lira SA, Shakhar G. Luminal bacteria recruit CD103+ dendritic cells into the intestinal epithelium to sample bacterial antigens for presentation. Immunity. 2013; 38:581-595. [PubMed: 23395676]

22. Mazzini E, Massimiliano L, Penna G, Rescigno M. Oral tolerance can be established via gap junction transfer of fed antigens from CX3CR1(+) macrophages to CD103(+) dendritic cells. Immunity. 2014; 40:248-261. [PubMed: 24462723]

23. Marelli G, Belgiovine C, Mantovani A, Erreni M, Allavena P. Non-redundant role of the chemokine receptor CX3CR1 in the anti-inflammatory function of gut macrophages. Immunobiology. 2017; 222:463-472. [PubMed: 27707514] 
24. Coombes JL, Siddiqui KR, Arancibia-Carcamo CV, Hall J, Sun CM, Belkaid Y, Powrie F. A functionally specialized population of mucosal CD103+ DCs induces Foxp3+ regulatory T cells via a TGF-beta and retinoic acid-dependent mechanism. J. Exp. Med. 2007; 204:1757-1764. [PubMed: 17620361]

25. Persson EK, Scott CL, Mowat AM, Agace WW. Dendritic cell subsets in the intestinal lamina propria: ontogeny and function. Eur. J. Immunol. 2013; 43:3098-3107. [PubMed: 23966272]

26. Sun CM, Hall JA, Blank RB, Bouladoux N, Oukka M, Mora JR, Belkaid Y. Small intestine lamina propria dendritic cells promote de novo generation of Foxp3 T reg cells via retinoic acid. J. Exp. Med. 2007; 204:1775-1785. [PubMed: 17620362]

27. Cassani B, Villablanca EJ, Quintana FJ, Love PE, Lacy-Hulbert A, Blaner WS, Sparwasser T, Snapper SB, Weiner HL, Mora JR. Gut-tropic T cells that express integrin alpha4beta7 and CCR9 are required for induction of oral immune tolerance in mice. Gastroenterology. 2011; 141:2109_ 2118. [PubMed: 21925467]

28. Gri G, Piconese S, Frossi B, Manfroi V, Merluzzi S, Tripodo C, Viola A, Odom S, Rivera J, Colombo MP, Pucillo CE. CD4+CD25+ regulatory T cells suppress mast cell degranulation and allergic responses through OX40-OX40L interaction. Immunity. 2008; 29:771-781. [PubMed: 18993084]

29. Weiner HL, da Cunha AP, Quintana F, Wu H. Oral tolerance. Immunol. Rev. 2011; 241:241-259. [PubMed: 21488901]

30. Hadis U, Wahl B, Schulz O, Hardtke-Wolenski M, Schippers A, Wagner N, Muller W, Sparwasser T, Forster R, Pabst O. Intestinal tolerance requires gut homing and expansion of FoxP3+ regulatory $\mathrm{T}$ cells in the lamina propria. Immunity. 2011; 34:237-246. [PubMed: 21333554]

31. Murai M, Turovskaya O, Kim G, Madan R, Karp CL, Cheroutre H, Kronenberg M. Interleukin 10 acts on regulatory $\mathrm{T}$ cells to maintain expression of the transcription factor Foxp3 and suppressive function in mice with colitis. Nat. Immunol. 2009; 10:1178-1184. [PubMed: 19783988]

32. Tordesillas L, Goswami R, Benede S, Grishina G, Dunkin D, Jarvinen KM, Maleki SJ, Sampson HA, Berin MC. Skin exposure promotes a Th2-dependent sensitization to peanut allergens. J. Clin. Invest. 2014; 124:4965-4975. [PubMed: 25295541]

33. Han H, Roan F, Ziegler SF. The atopic march: current insights into skin barrier dysfunction and epithelial cell-derived cytokines. Immunol. Rev. 2017; 278:116-130. [PubMed: 28658558]

34. Venkataraman D, Soto-Ramirez N, Kurukulaaratchy RJ, Holloway JW, Karmaus W, Ewart SL, Arshad SH, Erlewyn-Lajeunesse M. Filaggrin loss-offunction mutations are associated with food allergy in childhood and adolescence. J. Allergy Clin. Immunol. 2014; 134:876-882 e874. [PubMed: 25174864]

35. Divekar R, Kita H. Recent advances in epithelium-derived cytokines (IL-33, IL-25, and thymic stromal lymphopoietin) and allergic inflammation. Curr. Opin. Allergy Clin. Immunol. 2015; 15:98-103. [PubMed: 25479313]

36. Lee JB, Chen CY, Liu B, Mugge L, Angkasekwinai P, Facchinetti V, Dong C, Liu YJ, Rothenberg ME, Hogan SP, Finkelman FD, Wang YH. IL-25 and CD4(+) TH2 cells enhance type 2 innate lymphoid cell-derived IL-13 production, which promotes IgE-mediated experimental food allergy. J. Allergy Clin. Immunol. 2016; 137:1216-1225. e1211-1215. [PubMed: 26560039]

37. von Moltke J, Ji M, Liang HE, Locksley RM. Tuft-cell-derived IL-25 regulates an intestinal ILC2epithelial response circuit. Nature. 2016; 529:221-225. [PubMed: 26675736]

38. Shik D, Tomar S, Lee JB, Chen CY, Smith A, Wang YH. IL-9-producing cells in the development of IgE-mediated food allergy. Semin. Immunopathol. 2017; 39:69-77. [PubMed: 27909880]

39. Yao W, Zhang Y, Jabeen R, Nguyen ET, Wilkes DS, Tepper RS, Kaplan MH, Zhou B. Interleukin-9 is required for allergic airway inflammation mediated by the cytokine TSLP. Immunity. 2013; 38:360-372. [PubMed: 23376058]

40. Brough HA, Cousins DJ, Munteanu A, Wong YF, Sudra A, Makinson K, Stephens AC, Arno M, Ciortuz L, Lack G, Turcanu V. IL-9 is a key component of memory TH cell peanut-specific responses from children with peanut allergy. J. Allergy Clin. Immunol. 2014; 134:1329-1338 e1310. [PubMed: 25112699]

41. Angkasekwinai P, Chang SH, Thapa M, Watarai H, Dong C. Regulation of IL-9 expression by IL-25 signaling. Nat. Immunol. 2010; 11:250-256. [PubMed: 20154671] 
42. Sehra S, Yao W, Nguyen ET, Glosson-Byers NL, Akhtar N, Zhou B, Kaplan MH. TH9 cells are required for tissue mast cell accumulation during allergic inflammation. J. Allergy Clin. Immunol. 2015; 136:433-440 e431. [PubMed: 25746972]

43. Noval Rivas M, Burton OT, Oettgen HC, Chatila T. IL-4 production by group 2 innate lymphoid cells promotes food allergy by blocking regulatory T-cell function. J. Allergy Clin. Immunol. 2016; 138:801-811 e809. [PubMed: 27177780]

44. Soumelis V, Reche PA, Kanzler H, Yuan W, Edward G, Homey B, Gilliet M, Ho S, Antonenko S, Lauerma A, Smith K, Gorman D, Zurawski S, Abrams J, Menon S, McClanahan T, de WaalMalefyt R, Bazan F, Kastelein RA, Liu YJ. Human epithelial cells trigger dendritic cell mediated allergic inflammation by producing TSLP. Nat. Immunol. 2002; 3:673-680. [PubMed: 12055625]

45. Ito T, Wang YH, Duramad O, Hori T, Delespesse GJ, Watanabe N, Qin FX, Yao Z, Cao W, Liu YJ. TSLP-activated dendritic cells induce an inflammatory T helper type 2 cell response through OX40 ligand. J. Exp. Med. 2005; 202:1213-1223. [PubMed: 16275760]

46. Pattarini L, Trichot C, Bogiatzi S, Grandclaudon M, Meller S, Keuylian Z, Durand M, Volpe E, Madonna S, Cavani A, Chiricozzi A, Romanelli M, Hori T, Hovnanian A, Homey B, Soumelis V. TSLP-activated dendritic cells induce human T follicular helper cell differentiation through OX40ligand. J. Exp. Med. 2017; 214:1529-1546. [PubMed: 28428203]

47. Klose CS, Artis D. Innate lymphoid cells as regulators of immunity, inflammation and tissue homeostasis. Nat. Immunol. 2016; 17:765-774. [PubMed: 27328006]

48. Mirchandani AS, Besnard AG, Yip E, Scott C, Bain CC, Cerovic V, Salmond RJ, Liew FY. Type 2 innate lymphoid cells drive CD4+ Th2 cell responses. J. Immunol. 2014; 192:2442-2448.

[PubMed: 24470502]

49. Noval Rivas M, Burton OT, Wise P, Charbonnier LM, Georgiev P, Oettgen HC, Rachid R, Chatila TA. Regulatory T cell reprogramming toward a Th2-cell-like lineage impairs oral tolerance and promotes food allergy. Immunity. 2015; 42:512-523. [PubMed: 25769611]

50. Johnston LK, Hsu CL, Krier-Burris RA, Chhiba KD, Chien KB, McKenzie A, Berdnikovs S, Bryce PJ. IL-33 precedes IL-5 in regulating eosinophil commitment and is required for eosinophil homeostasis. J. Immunol. 2016; 197:3445-3453. [PubMed: 27683753]

51. Van Dyken SJ, Mohapatra A, Nussbaum JC, Molofsky AB, Thornton EE, Ziegler SF, McKenzie AN, Krummel MF, Liang HE, Locksley RM. Chitin activates parallel immune modules that direct distinct inflammatory responses via innate lymphoid type 2 and gammadelta T cells. Immunity. 2014; 40:414-424. [PubMed: 24631157]

52. Halim TYF, Steer CA, Mathä L, Gold MJ, Martinez-Gonzalez I, McNagny KM, McKenzie ANJ, Takei F. Group 2 innate lymphoid cells are critical for the initiation of adaptive T helper 2 cellmediated allergic lung inflammation. Immunity. 2014; 40:425-435. [PubMed: 24613091]

53. Wambre E, DeLong JH, James EA, Torres-Chinn N, Pfutzner W, Mobs C, Durham SR, Till SJ, Robinson D, Kwok WW. Specific immunotherapy modifies allergen-specific CD4(+) T-cell responses in an epitope-dependent manner. J. Allergy Clin. Immunol. 2014; 133:872-879 e877. [PubMed: 24373351]

54. Ryan JF, Hovde R, Glanville J, Lyu SC, Ji X, Gupta S, Tibshirani RJ, Jay DC, Boyd SD, Chinthrajah RS, Davis MM, Galli SJ, Maecker HT, Nadeau KC. Successful immunotherapy induces previously unidentified allergen-specific CD4+ T-cell subsets. Proc. Natl. Acad. Sci. U. S. A. 2016; 113:E1286-1295. [PubMed: 26811452]

55. Syed A, Garcia MA, Lyu SC, Bucayu R, Kohli A, Ishida S, Berglund JP, Tsai M, Maecker H, O'Riordan G, Galli SJ, Nadeau KC. Peanut oral immunotherapy results in increased antigeninduced regulatory T-cell function and hypomethylation of forkhead box protein 3 (FOXP3). J. Allergy Clin. Immunol. 2014; 133:500-510 e511. [PubMed: 24636474]

56. Meiler F, Klunker S, Zimmermann M, Akdis CA, Akdis M. Distinct regulation of IgE, IgG4 and IgA by T regulatory cells and toll-like receptors. Allergy. 2008; 63:1455-1463. [PubMed: 18925882]

57. Sugimoto M, Kamemura N, Nagao M, Irahara M, Kagami S, Fujisawa T, Kido H. Differential response in allergen-specific IgE, IgGs, and IgA levels for predicting outcome of oral immunotherapy. Pediatr. Allergy Immunol. 2016; 27:276-282. [PubMed: 26764899] 
58. van de Veen W, Stanic B, Yaman G, Wawrzyniak M, Söllner S, Akdis DG, Rückert B, Akdis CA, Akdis M. IgG4 production is confined to human IL-10-producing regulatory B cells that suppress antigen-specific immune responses. J. Allergy Clin. Immunol. 2013; 131:1204-1212. [PubMed: 23453135]

59. Boonpiyathad T, Meyer N, Moniuszko M, Sokolowska M, Eljaszewicz A, Wirz OF, TomasiakLozowska MM, Bodzenta-Lukaszyk A, Ruxrungtham K, van de Veen W. High-dose bee venom exposure induces similar tolerogenic B-cell responses in allergic patients and healthy beekeepers. Allergy. 2017; 72:407-415. [PubMed: 27341567]

60. Kim HS, Kim AR, Kim DK, Kim HW, Park YH, Jang GH, Kim B, Park YM, You JS, Kim HS, Beaven MA, Kim YM, Choi WS. Interleukin-10-producing CD5+ B cells inhibit mast cells during immunoglobulin E-mediated allergic responses. Nat. Sci. Signal. 2015; 8:ra28.

61. Santos AF, James LK, Bahnson HT, Shamji MH, Couto-Francisco NC, Islam S, Houghton S, Clark AT, Stephens A, Turcanu V, Durham SR, Gould HJ, Lack G. IgG4 inhibits peanut-induced basophil and mast cell activation in peanut-tolerant children sensitized to peanut major allergens. J. Allergy Clin. Immunol. 2015; 135:1249-1256. [PubMed: 25670011]

62. Akdis M, Akdis CA. Mechanisms of allergen-specific immunotherapy: multiple suppressor factors at work in immune tolerance to allergens. J. Allergy Clin. Immunol. 2014; 133:621-631. [PubMed: 24581429]

63. Matheu MP, Othy S, Greenberg ML, Dong TX, Schuijs M, Deswarte K, Hammad H, Lambrecht BN, Parker I, Cahalan MD. Imaging regulatory T cell dynamics and CTLA4-mediated suppression of T cell priming. Nat. Commun. 2015; 6:6219. [PubMed: 25653051]

64. Chu KH, Chiang BL. Characterization and functional studies of forkhead box protein 3(-) lymphocyte activation gene 3(+) CD4(+) regulatory T cells induced by mucosal B cells. Clin. Exp. Immunol. 2015; 180:316-328. [PubMed: 25581421]

65. Liang B, Workman C, Lee J, Chew C, Dale BM, Colonna L, Flores M, Li N, Schweighoffer E, Greenberg S, Tybulewicz V, Vignali D, Clynes R. Regulatory T cells inhibit dendritic cells by lymphocyte activation gene-3 engagement of MHC class II. J. Immunol. 2008; 180:5916-5926. [PubMed: 18424711]

66. Vignali DA, Collison LW, Workman CJ. How regulatory T cells work. Nat. Rev. Immunol. 2008; 8:523-532. [PubMed: 18566595]

67. Konstantinou GN, Nowak-Wegrzyn A, Bencharitiwong R, Bardina L, Sicherer SH, Sampson HA. Egg-white-specific IgA and IgA2 antibodies in egg-allergic children: is there a role in tolerance induction? Pediatr. Allergy Immunol. 2014; 25:64-70. [PubMed: 24118158]

68. Cianferoni, A., Saltzman, R., Saretta, F., Barni, S., Dudek, E., Kelleher, M., Spergel, JM. Invariant natural killer cells change after an oral allergy desensitization protocol for cow's milk. Clin. Exp. Allergy. 2017. http://dx.doi.org/10.1111/cea.12975

69. Burton OT, Tamayo JM, Stranks AJ, Koleoglou KJ, Oettgen HC. Allergen-specific IgG antibody signaling through FcgammaRIIb promotes food tolerance. J. Allergy Clin. Immunol. 2017

70. Freidl R, Gstoettner A, Baranyi U, Swoboda I, Stolz F, Focke-Tejkl M, Wekerle T, van Ree R, Valenta R, Linhart B. Blocking antibodies induced by immunization with a hypoallergenic parvalbumin mutant reduce allergic symptoms in a mouse model of fish allergy. J. Allergy Clin. Immunol. 2017; 139:1897-1905 e1891. [PubMed: 27876628]

71. Chang TW, Davis FM, Sun NC, Sun CR, MacGlashan DW Jr, Hamilton RG. Monoclonal antibodies specific for human IgE-producing B cells: a potential therapeutic for IgE-mediated allergic diseases. Biotechnology (N Y). 1990; 8:122-126. [PubMed: 1369991]

72. MacGlashan DW Jr, Bochner BS, Adelman DC, Jardieu PM, Togias A, McKenzie-White J, Sterbinsky SA, Hamilton RG, Lichtenstein LM. Down-regulation of Fc(epsilon)RI expression on human basophils during in vivo treatment of atopic patients with anti-IgE antibody. J. Immunol. 1997; 158:1438-1445. [PubMed: 9013989]

73. Beck LA, Marcotte GV, MacGlashan D, Togias A, Saini S. Omalizumab-induced reductions in mast cell FcepsilonRI expression and function. J. Allergy Clin. Immunol. 2004; 114:527-530. [PubMed: 15356552] 
74. Prussin C, Griffith DT, Boesel KM, Lin H, Foster B, Casale TB. Omalizumab treatment downregulates dendritic cell FcepsilonRI expression. J. Allergy Clin. Immunol. 2003; 112:11471154. [PubMed: 14657874]

75. Chang TW, Wu PC, Hsu CL, Hung AF. Anti-IgE antibodies for the treatment of IgE-mediated allergic diseases. Adv. Immunol. 2007; 93:63-119. [PubMed: 17383539]

76. Wood RA, Kim JS, Lindblad R, Nadeau K, Henning AK, Dawson P, Plaut M, Sampson HA. A randomized, double-blind, placebo-controlled study of omalizumab combined with oral immunotherapy for the treatment of cow's milk allergy. J. Allergy Clin. Immunol. 2015; 137:1103-1110. e1101-1111. [PubMed: 26581915]

77. Frischmeyer-Guerrerio, PA., Masilamani, M., Gu, W., Brittain, E., Wood, R., Kim, J., Nadeau, K., Jarvinen, KM., Grishin, A., Lindblad, R., Sampson, HA. Mechanistic correlates of clinical responses to omalizumab in the setting of oral immunotherapy for milk allergy. J. Allergy Clin. Immunol. 2017. http://dx.doi.org/10.1016/j.jaci.2017.1003.1028

78. MacGinnitie AJ, Rachid R, Gragg H, Little SV, Lakin P, Cianferoni A, Heimall J, Makhija M, Robison R, Chinthrajah RS, Lee J, Lebovidge J, Dominguez T, Rooney C, Lewis MO, Koss J, Burke-Roberts E, Chin K, Logvinenko T, Pongracic JA, Umetsu DT, Spergel J, Nadeau KC, Schneider LC. Omalizumab facilitates rapid oral desensitization for peanut allergy. J. Allergy Clin. Immunol. 2016; 139:873-881 e878. [PubMed: 27609658]

79. Begin P, Dominguez T, Wilson SP, Bacal L, Mehrotra A, Kausch B, Trela A, Tavassoli M, Hoyte E, O'Riordan G, Blakemore A, Seki S, Hamilton RG, Nadeau KC. Phase 1 results of safety and tolerability in a rush oral immunotherapy protocol to multiple foods using Omalizumab. Allergy Asthma Clin Immunol. 2014; 10:7. [PubMed: 24576338]

80. Begin P, Winterroth LC, Dominguez T, Wilson SP, Bacal L, Mehrotra A, Kausch B, Trela A, Hoyte E, O'Riordan G, Seki S, Blakemore A, Woch M, Hamilton RG, Nadeau KC. Safety and feasibility of oral immunotherapy to multiple allergens for food allergy. Allergy Asthma Clin Immunol. 2014; 10:1. [PubMed: 24428859]

81. Begin P, Nadeau KC. Changes in peanut-specific T-cell clonotype with oral immunotherapy. J. Allergy Clin. Immunol. 2015; 135:1636-1638. [PubMed: 25930192]

82. Pennington LF, Tarchevskaya S, Brigger D, Sathiyamoorthy K, Graham MT, Nadeau KC, Eggel A, Jardetzky TS. Structural basis of omalizumab therapy and omalizumab-mediated IgE exchange. Nat. Commun. 2016; 7:11610. [PubMed: 27194387]

83. van Neerven RJ, Wikborg T, Lund G, Jacobsen B, Brinch-Nielsen A, Arnved J, Ipsen H. Blocking antibodies induced by specific allergy vaccination prevent the activation of CD4+ T cells by inhibiting serum-IgE-facilitated allergen presentation. J. Immunol. 1999; 163:2944-2952. [PubMed: 10453043]

84. Larche M, Akdis CA, Valenta R. Immunological mechanisms of allergen-specific immunotherapy. Nat. Rev. Immunol. 2006; 6:761-771. [PubMed: 16998509]

85. Selb R, Eckl-Dorna J, Neunkirchner A, Schmetterer K, Marth K, Gamper J, Jahn-Schmid B, Pickl WF, Valenta R, Niederberger V. CD23 surface density on B cells is associated with IgE levels and determines IgE-facilitated allergen uptake as well as activation of allergen-specific T cells. J. Allergy Clin. Immunol. 2017; 139:290-299 e294. [PubMed: 27372566]

86. Selb R, Eckl-Dorna J, Twaroch TE, Lupinek C, Teufelberger A, Hofer G, Focke-Tejkl M, Gepp B, Linhart B, Breiteneder H, Ellinger A, Keller W, Roux KH, Valenta R, Niederberger V. Critical and direct involvement of the CD23 stalk region in IgE binding. J. Allergy Clin. Immunol. 2017; 139:281-289 e285. [PubMed: 27343203]

87. Zieglmayer P, Focke-Tejkl M, Schmutz R, Lemell P, Zieglmayer R, Weber M, Kiss R, Blatt K, Valent P, Stolz F, Huber H, Neubauer A, Knoll A, Horak F, Henning R, Valenta R. Mechanisms, safety and efficacy of a B cell epitope-based vaccine for immunotherapy of grass pollen allergy. EBioMedicine. 2016; 11:43-57. [PubMed: 27650868]

88. Chu DK, Llop-Guevara A, Walker TD, Flader K, Goncharova S, Boudreau JE, Moore CL, In TS, Waserman S, Coyle AJ, Kolbeck R, Humbles AA, Jordana M. IL-33 but not thymic stromal lymphopoietin or IL-25, is central to mite and peanut allergic sensitization. J. Allergy Clin. Immunol. 2013; 131:187-200. e181-188. [PubMed: 23006545]

89. Londei M, Kenney B, Los G, Marino MH. A phase 1 study of ANB020, an anti-IL-33 monoclonal antibody in healthy volunteers. J. Allergy Clin. Immunol. 2017; 139:AB73. 
90. Assa'ad AH, Gupta SK, Collins MH, Thomson M, Heath AT, Smith DA, Perschy TL, Jurgensen $\mathrm{CH}$, Ortega HG, Aceves SS. An antibody against IL-5 reduces numbers of esophageal intraepithelial eosinophils in children with eosinophilic esophagitis. Gastroenterology. 2011; 141:1593-1604. [PubMed: 21835135]

91. Spergel JM, Rothenberg ME, Collins MH, Furuta GT, Markowitz JE, Fuchs G III, O’Gorman MA, Abonia JP, Young J, Henkel T, Wilkins HJ, Liacouras CA. Reslizumab in children and adolescents with eosinophilic esophagitis: results of a double-blind, randomized, placebo-controlled trial. J. Allergy Clin. Immunol. 2012; 129:456-463. 463 e451-453. [PubMed: 22206777]

92. Tang ML, Ponsonby AL, Orsini F, Tey D, Robinson M, Su EL, Licciardi P, Burks W, Donath S. Administration of a probiotic with peanut oral immunotherapy: a randomized trial. J. Allergy Clin. Immunol. 2015; 135:737-744 e738. [PubMed: 25592987]

93. Burks AW, Wood RA, Jones SM, Sicherer SH, Fleischer DM, Scurlock AM, Vickery BP, Liu AH, Henning AK, Lindblad R, Dawson P, Plaut M, Sampson HA. Consortium of Food Allergy Research Sublingual immunotherapy for peanut allergy: long-term follow-up of a randomized multicenter trial. J. Allergy Clin. Immunol. 2015; 135:1240-1248. e1241-1243. [PubMed: 25656999]

94. Pellerin, L., Jenks, JA., Chinthrajah, S., Dominguez, T., Block, W., Zhou, X., Noshirvan, A., Gregori, S., Roncarolo, MG., Nadeau, KC., Bacchetta, R. Peanut-specific Tr1 cells induced in vitro from allergic individuals are functionally impaired. J. Allergy Clin. Immunol. 2017. http:// dx.doi.org/10.1016/j.jaci.2017.1005.1045 


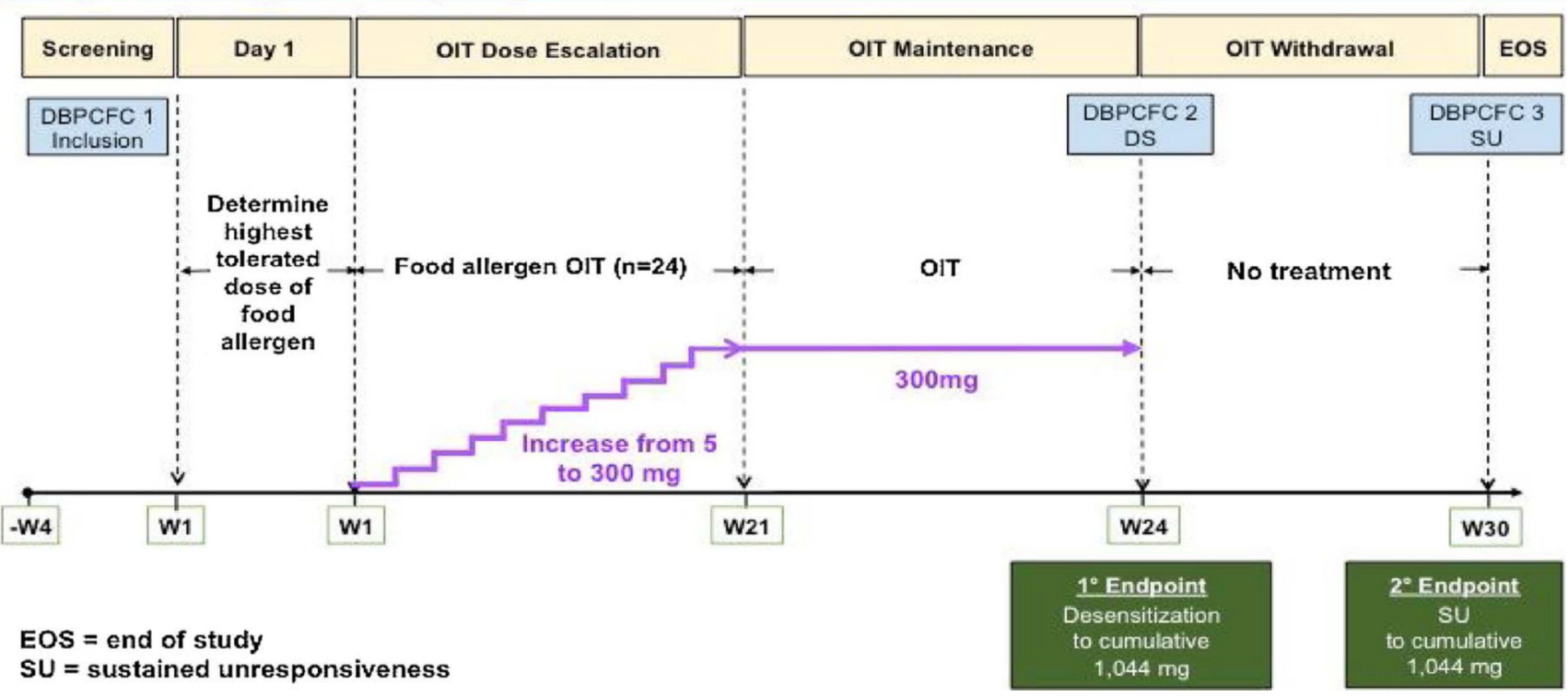

Fig. 1.

Example food allergen OIT study design. 


\section{Lumen}
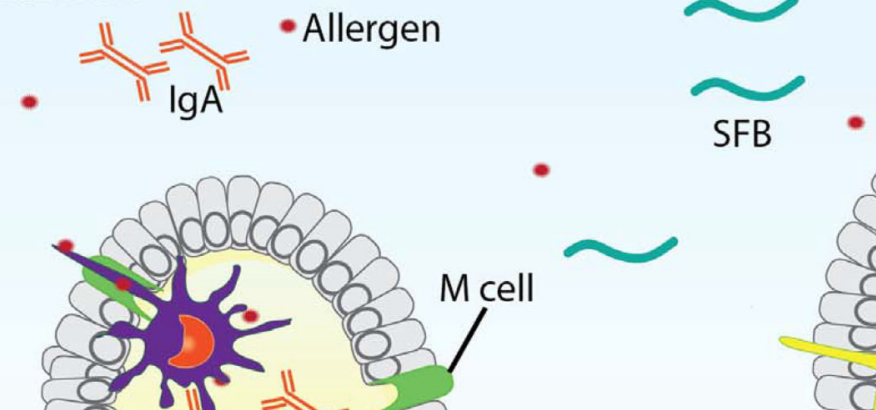

Epithelial cell

Lamina propria

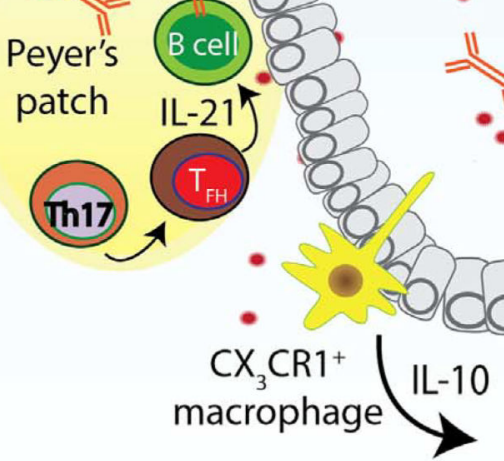

Lymph node
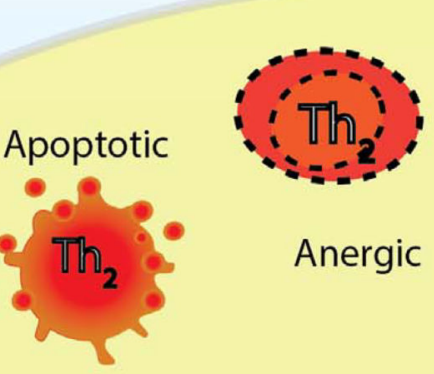

Anergic
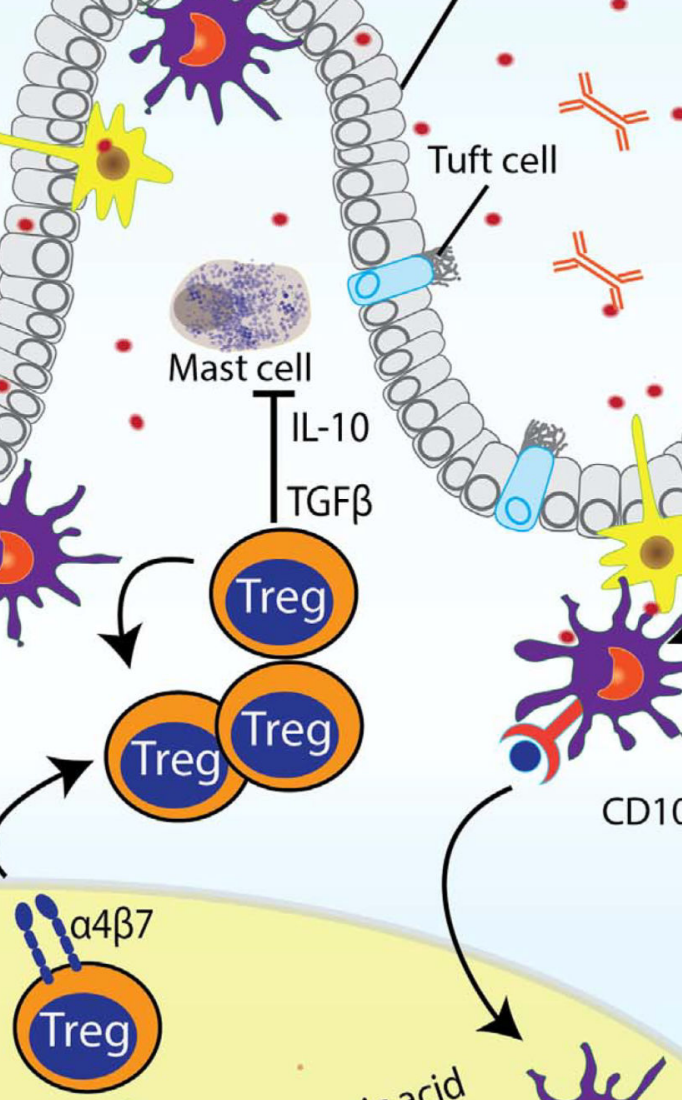

Tuft cell

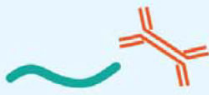




\section{Lumen}

Epithelial

-Allergen

damage
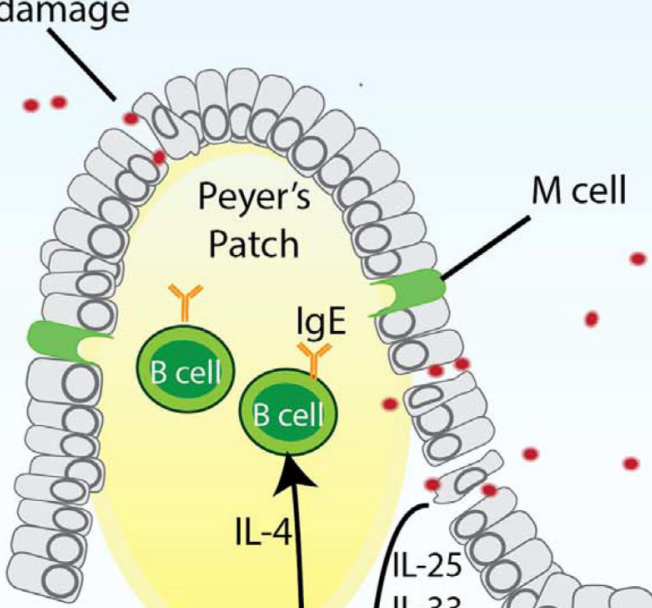

$\lg \mathrm{E}$

Lamina propria

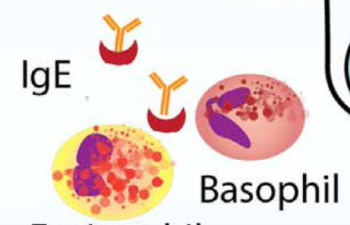

Eosinophil
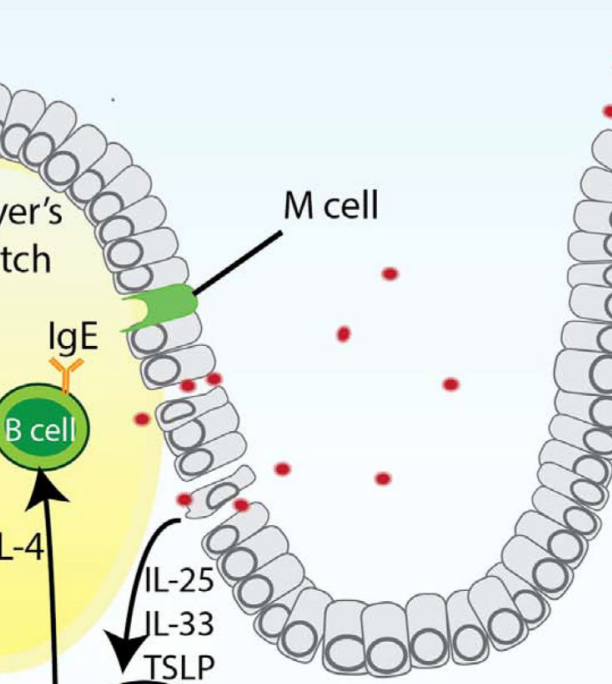

()
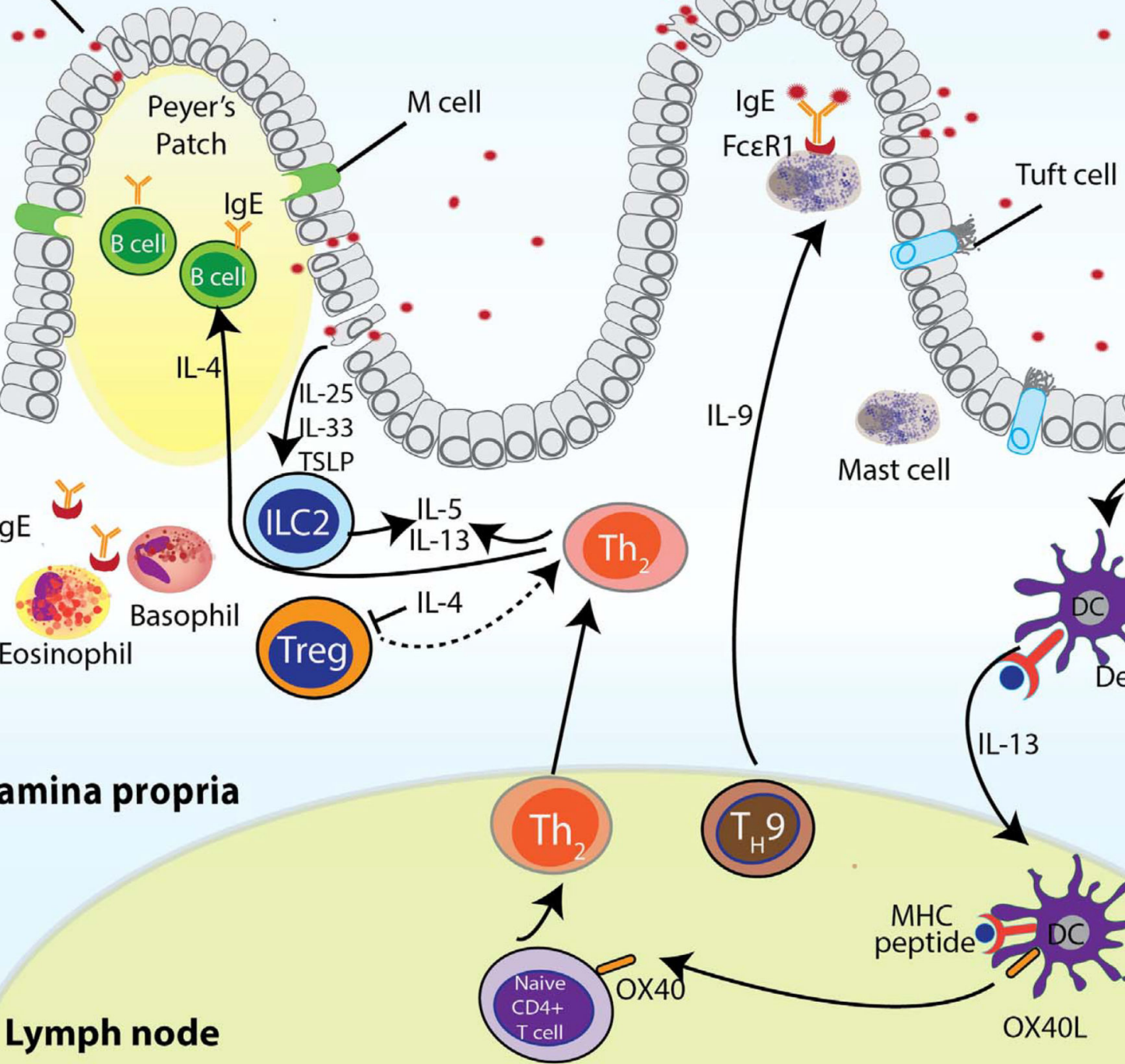

Fig. 3.

T helper 2 cell-mediated atopic response to food antigens. 


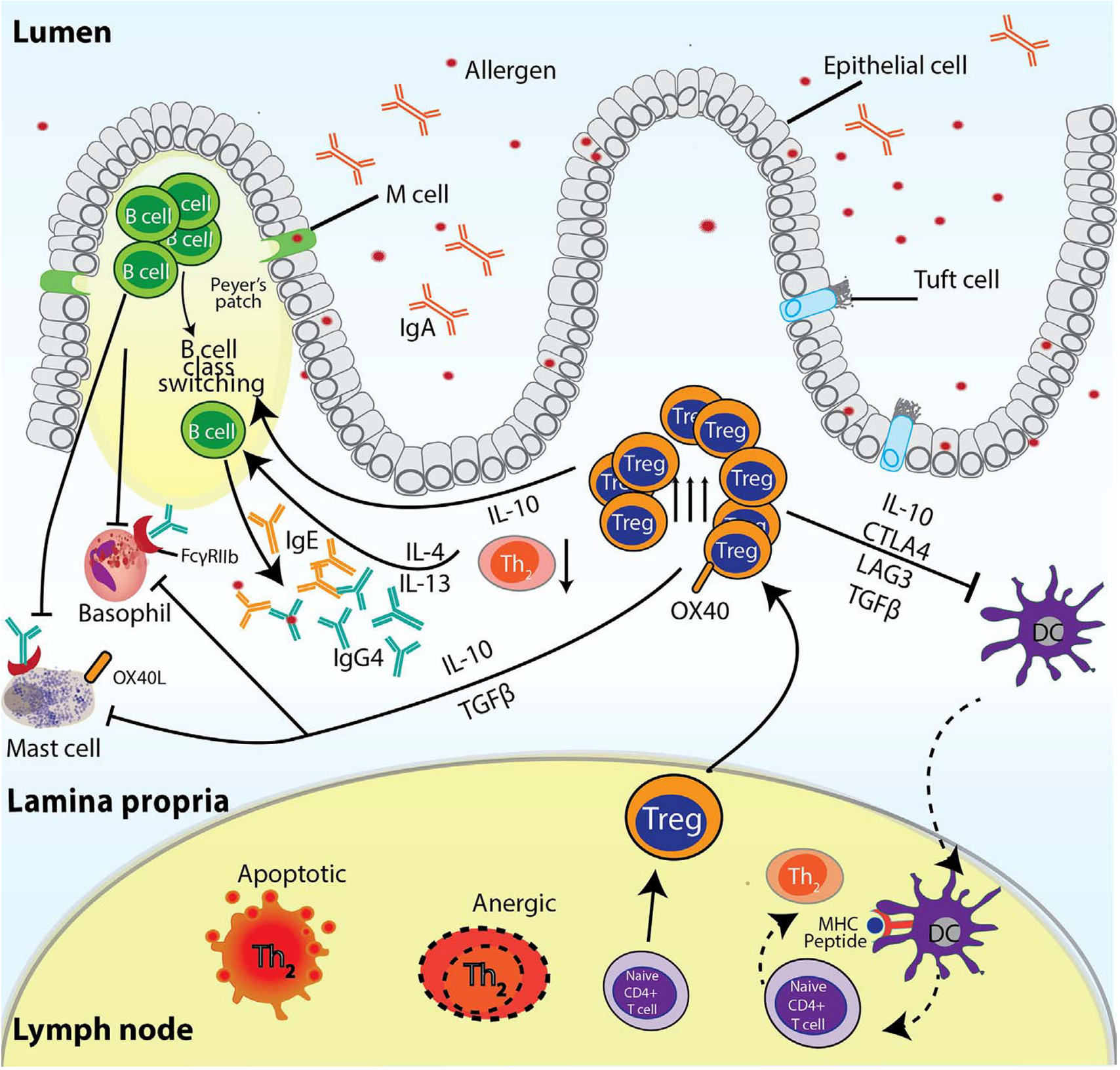

Fig. 4.

Immune cell types and cytokines involved in desensitization to food antigens. 


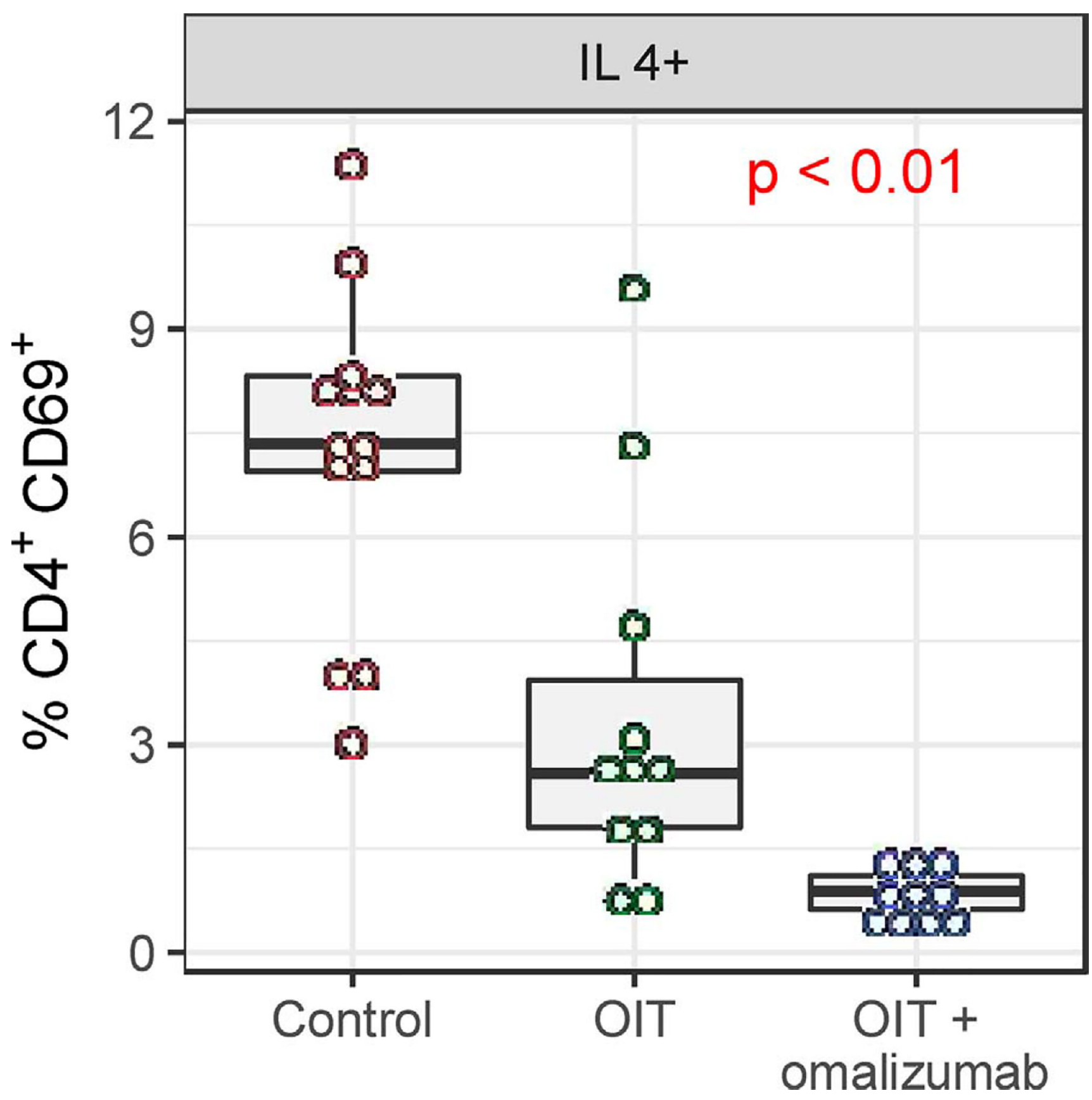

Fig. 5.

Percentages of peanut-specific CD4 ${ }^{+} \mathrm{T}$ cells expressing IL-4 in each participant group ( $p$ value determined by Kruskal-Wallis test). 


\section{Table 1}

Examples of OIT strategies.

\begin{tabular}{lll}
\hline Form of OIT & Type of drug & Mechanism \\
\hline Prevention & Oral allergen administration & Effects may include increased function of Ag-specific CD4 ${ }^{+} \mathrm{FOXP}^{+} \mathrm{T}_{\text {reg }}$ \\
Treatment & Oral allergen administration & Effects may include increased function of Ag-specific CD4 ${ }^{+}$FOXP3 ${ }^{+} \mathrm{T}_{\text {reg }}$ \\
With adjunct omalizumab & Humanized mouse mAb to IgE & Binds free and membrane-bound IgE, but not IgE bound to FceRI or CD23 \\
With adjunct mepolizumab & Humanized mouse mAb to IL-5 & Blocks IL-5-mediated signaling (Fig. 2) \\
With adjunct rezlisumab & Humanized mouse mAb to IL-5 & Blocks IL-5-mediated signaling (Fig. 2) \\
With adjunct ANB020 & Humanized mAb to IL-33 & Blocks IL-33-mediated signaling (Fig. 2) \\
\hline
\end{tabular}

